\title{
A POSSIBLE ROLE OF Z PROTEIN IN DIETARY CONTROL OF HEPATIC TRIACYLGLYCEROL SYNTHESIS
}

\author{
Nobuko IRITANI, Eiko FUKUDA, and Kaeko INOGUCHI ${ }^{1}$ \\ Tezukayama Gakuin College, \\ Sumiyoshi-ku, Osaka 558, Japan \\ (Received January 28, 1980)
}

\begin{abstract}
Summary The effects of fasting and refeeding on hepatic $\mathrm{Z}$ protein were investigated in rats. When $\left[\mathrm{U}-{ }^{14} \mathrm{C}\right]$ palmityl-CoA was added to the liver cytosol fraction from fat-free refed rats, more binding of labeled palmityl-CoA to the Z-protein region was found than in the case of fasted rats. Also the radioactivities in specific precipitations of the palmityl-CoA binding protein with anti- $Z$ immunoglobulin $G$ were higher in the refed rats. The $Z$ protein which stimulated diacylglycerol acyltransferase may be involved in the change of triacylglycerol synthesis in fasted and refed rat livers.
\end{abstract}

Keywords Z protein, diacylglycerol acyltransferase, fasting and refeeding

Although the individual reactions in microsomal pathways of triacylglycerol synthesis in liver and other tissues are well defined (1-3), the factors which regulate the overall rate of liver triacylglycerol formation are not yet clear. Fallon et al. demonstrated that in rats fed on a high carbohydrate diet triacylglycerol formation in liver increased and correlated well with the activities of microsomal glycerophosphate acyltransferase and phosphatidate phosphatase (3-5). On the other hand, in a previous study using rat liver slices it was shown that triacylglycerol synthesis was markedly affected by fasting or refeeding the animals, phospholipid synthesis being virtually constant (6). It was suggested from the results that the syntheses of triacylglycerols and phospholipids are independently controlled. In view of the fact that triacylglycerols and phospholipids in liver are synthesized from $\alpha$ glycerophosphate to 1,2-diacylglycerol in a common pathway(1), it seems reasonable to postulate that the synthesis of both lipids is regulated after the 1,2diacylglycerol step rather than during the common steps. The present report provides evidence that the binding activity of palmityl-CoA to the $\mathrm{Z}$ protein, which is present in the cytosol of liver (7-9) and stimulates the activity of diacylglycerol acyltransferase (10), was higher in refed rats than in fasted rats.

\footnotetext{
1 入谷信子, 福田栄子, 井ノ口加枝子
} 


\section{MATERIALS AND METHODS}

Male Wistar rats (about $200 \mathrm{~g}$ ) maintained ad libitum on a standard stock diet (Oriental Yeast Co., type MF) were fasted for 2 days and then refed on a fat-free diet for the following 2 days. The fat-free diet was the same as used previously (11). Rats were killed by decapitation between 10 and 11 a.m., the livers of 3 rats being pooled, homogenization being carried out with 2 volumes of $0.25 \mathrm{M}$ sucrose. The microsomal fraction (between $10,000 \mathrm{~g}$ and $105,000 \mathrm{~g}$ ) and the $105,000 \mathrm{~g}$ supernatant fraction were obtained for the following experiments.

The supernatant fraction of the liver homogenate was mixed with [U${ }^{14} \mathrm{C}$ ]palmityl-CoA and chromatographed on a Sephadex column. Elution was performed with $0.01 \mathrm{M}$ potassium phosphate buffer, $\mathrm{pH} 7.4$, containing $0.1 \mathrm{M} \mathrm{NaCl}$ at $4{ }^{\circ} \mathrm{C}$. Using aliquots of the eluate, the protein concentration thereof was measured by absorbance at $280 \mathrm{~nm}$. To $0.5 \mathrm{ml}$ of the eluate was added $4.5 \mathrm{ml}$ of scintillation fluid (150 mg POPOP and $4 \mathrm{~g}$ PPO in 1 liter toluene plus $500 \mathrm{ml}$ Triton
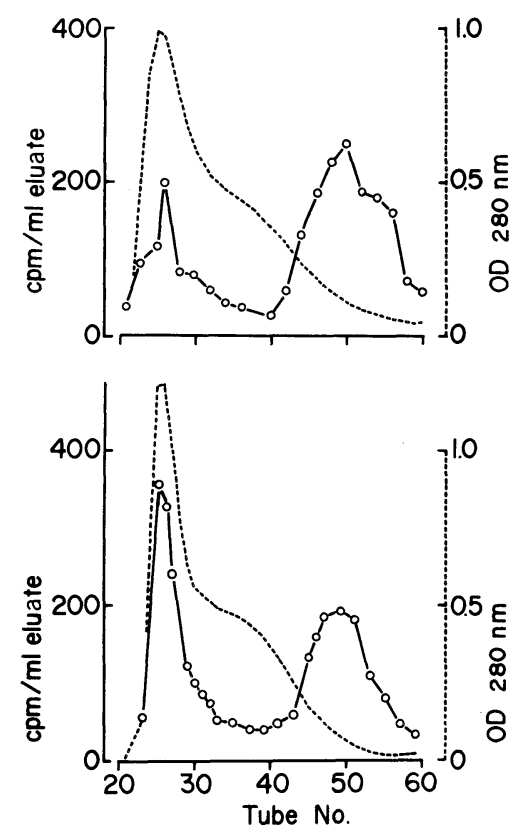

Fig. 1. Separation of $\left[\mathrm{U}-{ }^{14} \mathrm{C}\right]$ palmityl-CoA binding protein from liver supernatant of fasted (lower) and fat-free refed (upper) rats by Sephadex G-75 column chromatography. $105,000 \mathrm{~g}$ supernatant fractions $(39 \mathrm{mg})$ of liver homogenate were mixed with $10 \mathrm{nmoles}$ of palmityl-CoA $(0.2 \mu \mathrm{Ci})$ and chromatographed on a Sephadex G-75 column $(2 \times 60 \mathrm{~cm})$. Elution $(3 \mathrm{ml} /$ tube $)$ was performed with $0.01 \mathrm{M}$ potassium phosphate, $\mathrm{pH} 7.4$, containing $0.1 \mathrm{M} \mathrm{NaCl}$ at $4^{\circ} \mathrm{C}$. Fraction Nos. $42-59$. were collected for the $\mathrm{Z}$ regions. (The fractions were numbered in order of elution.) 
$\mathrm{X}-100)$. The radioactivities of protein-bound palmityl-CoA were measured by using a Packard-type 3385 scintillation counter. [U- $\left.{ }^{14} \mathrm{C}\right]$ Palmityl-CoA was purchased from the Radiochemical Centre, Amersham, U. K.

Aliquots of Z-protein region separated by the column chromatography (the same $Z$ region shown in Fig. 1) were mixed with labeled palmityl-CoA and then added to the partially purified anti- $Z$ immunoglobulin $G$. To another aliquot was added the same amount of control $\gamma$-globulin to determine non-specific precipitation. The mixture was left to stand at $4^{\circ} \mathrm{C}$ for 2 days. The precipitates were separated by centrifuging and washed twice with saline, subsequently being dissolved in alkaline solution and the radioactivities thereof measured.

The activity of diacylglycerol acyltransferase [EC 2.3.1.20] in liver microsomes was assayed as described in the footnote of Table 1. Termination of the reaction and extraction of labeled triacylglycerol were carried out according to Yamashita et al. (12).

Disc polyacrylamide gel electrophoresis of $\mathrm{Z}$ regions in the presence of sodium dodecylsulfate was performed essentially according to the method of Weber and Osborn (13).

Authentic $Z$ protein, which was purified essentially according to Ockner and Manning (14), and anti-Z immunoglobulin $G$ were generous gifts from Professor $T$. Hashimoto (School of Medicine, Shinshu University, Matsumoto, Japan). The anti-Z immunoglobulin $\mathrm{G}$, the antibody for one of the Z-protein fractions ( $\mathrm{p}$ I 7.6), was separated by isoelectric focusing(15). A single connecting band of precipitation was observed between Z-protein preparations with different isoelectric

Table 1. Stimulation of diacylglycerol acyltransferase activity in liver microsomes by $\mathrm{Z}$ protein.

\begin{tabular}{|c|c|c|}
\hline \multirow{2}{*}{$\begin{array}{l}\mathrm{Z} \text { protein addition } \\
\text { in assay medium }\end{array}$} & \multicolumn{2}{|c|}{ Diacylglycerol acyltransferase activity in liver microsome } \\
\hline & Fasted & Refed \\
\hline nmoles $/ 0.25 \mathrm{ml}$ & \multicolumn{2}{|c|}{$\mathrm{nmoles} / \mathrm{min} / \mathrm{mg}^{*}$} \\
\hline 0 & $1.64 \pm 0.43$ & $1.45 \pm 0.43$ \\
\hline 0.2 & $3.01 \pm 1.25$ & $3.03 \pm 1.12$ \\
\hline 2 & $3.60 \pm 1.22$ & $3.44 \pm 0.84^{\mathrm{a}}$ \\
\hline 4 & $3.99 \pm 1.33^{\mathrm{a}}$ & $3.21 \pm 1.04$ \\
\hline 10 & $3.65 \pm 0.82^{\mathrm{b}}$ & $3.64 \pm 0.89^{\mathrm{b}}$ \\
\hline
\end{tabular}

Mean \pm SD. (3 rats). *Products formed per min per mg protein of microsomes at $37^{\circ} \mathrm{C}$. Rats were fasted for 2 days and then refed on a fat-free diet for 2 days. The assay mixture contained $30 \mathrm{~mm}$ Tris- $\mathrm{HCl}, \mathrm{pH} 7.5,5.4 \mathrm{~mm} \mathrm{MgCl}_{2}, 2 \mathrm{~mm}$ DL-dithiothreitol, $4 \mathrm{~mm}$ diacylglycerol, and $0.1 \mathrm{~mm}$ palmityl-CoA. The reaction was initiated by adding $0.1 \mathrm{mg}$ of liver microsomes to $0.25 \mathrm{ml}$ of the mixture, and carried out at $37^{\circ} \mathrm{C}$ for $15 \mathrm{~min}$. The $Z$ protein was obtained from the liver of normal rats. Significantly different from non-addition of $\mathrm{Z}$ protein. ${ }^{\mathrm{a}} p<0.05,{ }^{\mathrm{b}} p<0.02$. 
points (pI 5.0, $\mathrm{p} I 5.3$ and 5.9, and $\mathrm{p} I$ 7.6) in Ouchterlony double-diffusion patterns (15).

\section{RESULTS AND DISCUSSION}

The $105,000 \mathrm{~g}$ supernatants of liver homogenate were mixed with labeled palmityl-CoA and chromatographed on Sephadex G-75. The chromatograms of palmityl-CoA bound to supernatant protein are shown in Fig. 1. The radioactivities of labeled palmityl-CoA bound to the Z-region protein were $51.9 \%$ and $73.5 \%$ of the total radioactivities bound to supernatant protein in the fasted rat and in the refed rat, respectively. The electrophoretic mobilities of the Z-region protein (the same as shown in Fig. 1) coincided with those of authentic $Z$ protein, as shown in Fig. 2. These findings are further demonstrated below immunologically.

The radioactivities of specific precipitations of labeled palmityl-CoA binding protein with anti- $Z$ immunoglobulin $G$ were higher in the refed group than in the fasted group, as shown in Fig. 3. When the $Z$ regions were reacted with control $\gamma$ -

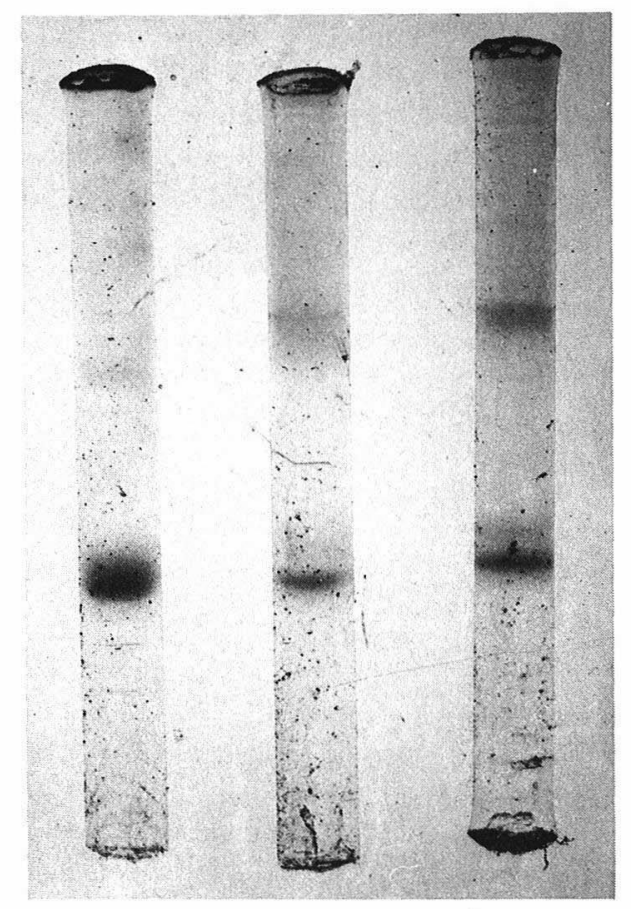

Fig. 2. Dodecylsulfate/polyacrylamide gel electrophoresis of authentic $Z$ protein (left), and Z-region proteins separated from liver supernatant of fasted (middle) and refed (right) rats. Samples $(40 \mu \mathrm{g})$ were applied to $10 \%$ gels run at $5 \mathrm{~mA} / \mathrm{gel}$ for $3 \mathrm{hr}$. Migration was toward the cathode at the bottom. 


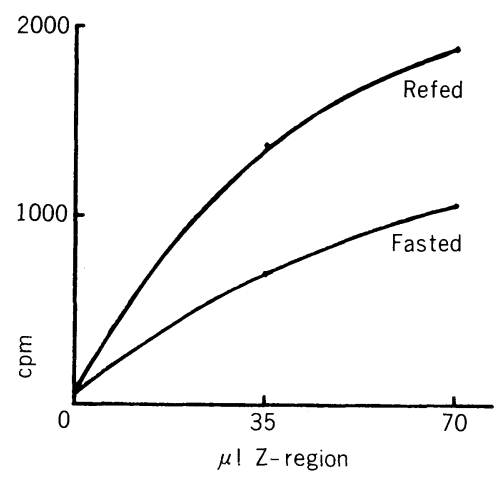

Fig. 3. Specific precipitation of $\left[\mathrm{U}-{ }^{14} \mathrm{C}\right]$ palmityl-CoA binding protein with anti-Z immunoglobulin $\mathrm{G}$. Aliquots of $\mathrm{Z}$ regions $(35$ or $70 \mu \mathrm{l}$ ) were mixed with 2 nmoles of palmityl-CoA $(0.04 \mu \mathrm{Ci})$ and then added to the partially purified anti- $Z$ immunoglobulin $\mathrm{G}(2.08 \mathrm{mg})$ in a mixture of $20 \mathrm{~mm}$ Tris- $\mathrm{HCl}$ buffer, $\mathrm{pH} 7.5,0.15 \mathrm{M} \mathrm{NaCl}$, $5 \mathrm{~mm} 2$-mercaptoethanol, and $1 \mathrm{~mm}$ EDTA. Radioactivities of the precipitates were measured.

globulin instead of anti-Z immunoglobulin $G$, almost no precipitation was found and the radioactivities of palmityl-CoA were recovered in the supernatant. The precipitations at $35 \mu \mathrm{l}$ of the Z-protein region in Fig. 3 seemed to be within linear ranges. From these, the results of immunoreaction were calculated as follows. Palmityl-CoA bound to $\mathrm{Z}$ protein was 0.67 and 1.27 nmoles $/ \mathrm{mg}$ protein of liver supernatant of the fasted and refed rats, respectively.

The effect of $Z$ protein on diacylglycerol acyltransferase of rat liver microsomes is shown in Table 1. When diacylglycerol acyltransferase was assayed in an assay medium in which the enzyme was fully activated, the activity of the enzyme increased about two-fold. The activity of diacylglycerol acyltransferase and also its activation by $\mathrm{Z}$ protein (from normal rats) were similar in the fasted and the refed rats. The activations of the enzyme by $Z$ proteins obtained from fasted and refed rats were also similar (data not shown). O'Doherty and Kuksis reported that the addition of increasing amounts of $Z$ protein resulted in 15 -fold stimulation of diacylglycerol acyltransferase activity in an assay medium with very low levels of substrates, as was the case with the addition of liver supernatant (10). Under these conditions we observed that the supernatant from refed rats was more stimulative than the supernatant from fasted rats (unpublished). In the present study, it was demonstrated that the binding activity of palmityl-CoA (a substrate for diacylglycerol acyltransferase) to $\mathrm{Z}$ protein was higher in refed rat liver than in fasted. However, it has not yet been made clear whether the quantity of $Z$ protein or the binding affinity of $Z$ protein to palmityl-CoA is changed. On polyacrylamide gel electrophoresis, the $\mathrm{Z}$ region of the refed group was dyed darker by Coomassie brilliant blue than that of the fasted group, as shown in Fig. 2. Therefore, it is 
suggested that the Z-protein quantity of liver cytosol may be increased by refeeding. With respect to the binding affinity, the stimulation of diacylglycerol acyltransferase in liver microsomes by $\mathrm{Z}$ protein was similar between the fasted and the refed group, as mentioned above. The changes of the binding affinity involved in fasting and refeeding have not yet been positively demonstrated. However, further investigation needs to be done to clarify these discussions. Although $\mathrm{Z}$ protein has a high affinity for fatty acid and acyl-CoA $(8,9,14)$, it seems unlikely to be a specific binder $(7,16)$. Thus, it is suggested that although the $\mathrm{Z}$ protein is not always a regulatory factor of triacylglycerol synthesis, it could be involved in the change of triacylglycerol synthesis in the fasted and the refed rat liver.

We would like to thank Professor T. Hashimoto for generous gifts of $\mathrm{Z}$ protein and anti-Z immunoglobulin G, and also Dr. K. Hosaka for stimulating discussions.

\section{REFERENCES}

1) Smith, S. W., Weiss, S. B., and Kennedy, E. P. (1957): The enzymatic dephosphorylation of phosphatidic acids. J. Biol. Chem., 228, 915-922.

2) Kennedy, E. P. (1961): Biosynthesis of complex lipids. Fed. Proc., 20, 934-940.

3) Lamb, R. G., and Fallon, H. J. (1974): An enzymatic explanation for dietary induced alterations in hepatic glycerolipid metabolism. Biochim. Biophys. Acta, 348, 179-188.

4) Fallon, H. J., and Kemp, E. L. (1968): Effects of diet on hepatic triglyceride synthesis. J. Clin. Invest., 47, 712-719.

5) Lamb, R. G., and Fallon, H. J. (1974): Glycerolipid formation from sn-glycerol-3phosphate by rat liver cell fractions: The role of phosphatidate phosphohydrolase. Biochim. Biophys. Acta, 348, 166-178.

6) Iritani, N., Yamashita, S., and Numa, S. (1976): Dietary control of triglyceride and phospholipid synthesis in rat liver slices. J. Biochem., 80, 217-222.

7) Levi, A. J., Gatmaitan, Z., and Arias, I. M. (1969): Two hepatic cytoplasmic protein fractions, $\mathrm{Y}$ and $\mathrm{Z}$, and their possible role in the hepatic uptake of bilirubin, sulfobromophthalein, and other anions. J. Clin. Invest., 48, 2156-2167.

8) Ockner, R. K., Manning, J. M., Poppenhausen, R. B., and Ho, W. K. L. (1972): A binding protein for fatty acids in cytosol of intestinal mucosa, liver myocardium and other tissues. Science, 177, 56-58.

9) Mishkin, S., Stein, L., Gatmaitan, Z., and Arias, I. M. (1972): The binding of fatty acids to cytoplasmic protein: Binding to $Z$ protein in liver and other tissues of the rat. Biochem. Biophys. Res. Commun., 47, 997-1003.

10) O'Doherty, P. J. A., and Kuksia, A. (1975): Stimulation of triacylglycerol synthesis by $\mathrm{Z}$ protein in rat liver and intestinal mucosa. FEBS Lett., 60, 256-258.

11) Iritani, N., Fukuda, E., and Ibamoto, K. (1977): Effect of fat intake on cholesterol turnover and bile acid formation. J. Nutr. Sci. Vitaminol., 23, 35-42.

12) Yamashita, S., Hosaka, K., Taketoh, M., and Numa, S. (1973): Acyl-donor specificities of partially purified 1-acylglycerophosphate acyltransferase, 2-acylglycerophosphate acyltransferase and 1-acylglycerophosphorylcholine acyltransferase from rat-liver microsomes. Eur. J. Biochem., 29, 235-238.

13) Weber, L., and Osborn, M. (1973): The reliability of molecular weight determinations by dodecyl sulfate polyacrylamide gel electrophoresis. J. Biol. Chem., 244, 4406-4412. 
14) Ockner, R. K., and Manning, J. A. (1974): Fatty acid binding protein in small intestine. Identification, isolation, and evidence for its role in cellular fatty acid transport. J. Clin. Invest., 54, 326-338.

15) Miyazawa, S., and Hashimoto, T. (1976): Effects of fatty acid binding proteins on fatty acid metabolism. Shinshu Igaku Zasshi (in Japanese), 27, 288-298.

16) Mishkin, S., Stein, L., Fleischner, G., Gatmaitan, Z., and Arias, I. M. (1973): On the function of $\mathrm{Z}$ portein in the liver. Gastroenterology, 64, 154. 